\title{
Akulturasi Nilai-Nilai Budaya Lokal dan Keagamaan dan Pengaruhnya terhadap Perilaku-Perilaku Sosial
}

\author{
Jurna Petri Roszi \\ STAI-YASTIS PADANG \\ jurnapetri_roszi@yahoo.co.id \\ Mutia \\ Institut Agama Islam Negeri (IAIN) Curup, Indonesia \\ mutia@iaincurup.ac.id
}

\begin{abstract}
This paper discusses the acculturation of Islam and traditions in the archipelago. The acculturation between Islam and local culture reinforces the concept of the harmony of Islam and local culture that can live hand in hand with their respective values, namely religious values and traditional values that have been acculturated and in direct contact. Acculturation is a concept to describe the long process of meeting two or more values between Islam and local values in which individuals, groups and communities live with the culture they already have. Historical and anthropological approaches are the approaches used in this study. Both of these approaches are used to observe and trace the processes that occur and the formation of a history that surrounds the community. From the search of history carried out it was found that Islam was inseparable from the influence of animist beliefs, dynamism, Hindu-Buddhist religion before Islam came. So that, when Islam comes and meets a pre-existing culture, it influences one another.
\end{abstract}

Keywords: Acculturation; harmony; local culture; the archipelago

\begin{abstract}
Abstrak
Tulisan ini membahas mengenai akulturasi Islam dan tradisi di Nusantara. Adanya akulturasi antara Islam dan budaya lokal menguatkan konsep adanya keharmonisan Islam dan budaya lokal yang bisa hidup bergandengan dengan nilai masing-masing, yaitu nilai-nilai agama dan nilai-nilai tradisi yang telah berakulturasi dan bersentuhan secara langsung. Akulturasi merupakan konsep untuk menggambarkan proses panjang bertemunya dua atau lebih tata nilai antara Islam dengan nilai-nilai lokal di mana individu, kelompok dan masyarakat bertempat tinggal dengan budaya yang telah dimilikinya. Pendekatan historis dan antropologis merupakan pendekatan yang dipakai dalam penelitian ini. Kedua pendekatan ini dipakai untuk mengamati dan menelusuri proses terjadi dan terbentuknya suatu sejarah yang melingkupi masyarakat tersebut. Dari penelusuran sejarah yang dilakukan ditemukan bahwa Islam tidak terlepas dari adanya pengaruh dari kepercayaan animisme, dinamisme, Hindu-Budha agama sebelum Islam datang. Sehingga, ketika Islam datang dan bertemu dengan kultur yang sudah ada sebelumnya, saling mempengaruhi antara yang satu dengan yang lainnya.
\end{abstract}

Kata Kunci: Akulturasi, harmoni, budaya lokal, dan nusantara

FOKUS : Jurnal Kajian Keislaman dan Kemasyarakatan Vol. 3, No. 2, 2018

P3M Sekolah Tinggi Agama Islam Negeri (STAIN) Curup - Bengkulu

Available online: http://journal.staincurup.ac.id/index.php/JF

p-ISSN 2548-334X, e-ISSN 2548-3358 


\section{PENDAHULUAN}

Indonesia adalah negara yang terdiri dari berbagai suku bangsa, yang masing-masing memiliki budaya yang berbeda-beda. Perbedaan itulah yang menjadi ciri khas dan keunggulan Indonesia. Di samping itu, Indonesia menjadi unik karena budayanya yang beragam. Keanekaragaman itu ditambah lagi dengan masuknya unsur-unsur budaya asing ke Indonesia. Masuknya budaya asing memperkaya warna kebudayaan Indonesia. Budaya asing itu sendiri masuk melalui tiga macam cara yaitu difusi, akulturasi, dan asimilasi.

Difusi merupakan proses penyebaran unsur-unsur kebudayaan ke seluruh dunia. Proses difusi tidak hanya dilihat dari berpindahnya unsurunsur budaya dari satu tempat ke tempat lain, akan tetapi dapat dilihat dari proses dibawanya dan diterimanya kebudayaan tersebut oleh individu. Kata akulturasi diartikan sebagai proses percampuran dua kebudayaan atau lebih yang saling bertemu dan saling mempengaruhi atau proses masuknya pengaruh kebudayaan asing terhadap suatu masyarakat, sebagian menyerap secara selektif' sedikit atau banyak unsur kebudayaan asing itu dan sebagian berusaha menolak pengaruh itu atau hasil pertemuan kebudayaan atau bahasa di antara anggota dua bahasa masyarakat, ditandai oleh peminjaman atau bilingualism. ${ }^{1}$ Asimilasi sebagai salah satu bentuk proses sosial erat kaitannya dengan proses dan pertemuan dua kebudayaan atau lebih. ${ }^{2}$

Sejak lama, para ahli antropologi tertarik pada peristiwa pertemuan dua kebudayaan atau lebih, terutama sejauh manakah hal tersebut dapat menyebabkan perubahan, baik sosial maupun budaya. Sementara itu, juga disadari bahwa berubahnya unsur-unsur suatu kebudayaan tidak selalu dapat diartikan sebagai kemajuan, namun dapat pula dianggap sebagai kemunduran. Untuk memahami pertemuan dua kebudayaan atau lebih di kalangan suku-suku bangsa dan kebudayaan di Indonesia yang beraneka warna, perlu dikaji berbagai bentuk interaksi sosial mereka. Kelompok sosial dan lembaga kemasyarakatan di kalangan suku bangsa tersebut adalah bentuk struktural dari masyarakat dan dinamikanya tergantung pada pola perilaku warganya dalam menghadapi suatu situasi tertentu.

${ }^{1}$ Hamzah Nunaid, "Asimilasi, Akulturasi, dan Integrasi Nasional”, Humaniora, 1999, hal 3

${ }^{2}$ Hari Purwanto, "Kajian Kritis Akulturasi Islam dengan Budaya Lokal", Sulesana, Vol. 8, No, 1, 2013, hal 3. 
Encyclopedia of Social Sciences (1957), Max Lerner meletakkan proses-proses sosial sebagai aspek dinamik dari hubungan-hubungan sosial. Sementara itu, dinamika suatu masyarakat tercermin dari perkembangan dan perubahan yang terjadi, baik sebagai akibat hubungan orang per orang, antar kelompok, maupun antara orang per orang dengan kelompok-kelompok. Berbagai bentuk interaksi sosial tersebut ditandai dengan terjadinya kontak dan komunikasi. Oleh karena itu, pengetahuan tentang proses-proses sosial akan dapat dipakai untuk mengetahui perilaku apakah yang akan terjadi, terutama apabila terjadi perubahanperubahan yang berakibat pada goyahnya sendi-sendi kehidupan lama.

Penggunaan istilah asimilasi di Indonesia kurang populer ketika mengkaji masalah integrasi nasional. Pada era 1960-an konsepsi tersebut lebih diartikan sebagai perkawinan campuran, terutama antara keturunan Cina dengan Bumiputera. Agar tidak diartikan sebagai perkawinan campuran, muncul padanan kata yang dipakai sebagai pengganti konsepsi asimilasi ialah pembauran. Kenyataannya, penggunaan istilah tersebut menjadi semakin tidak jelas, terutama jika dikaitkan dengan tujuan analisis, ruang lingkup dan pendekatan atas permasalahan yang akan dipecahkan dan dipahami. Sementara itu, di kalangan antropologi dan sosiologi, ruang lingkup konsepsi tersebut juga masih dijumpai perbedaan dan sering diartikan sama dengan konsepsi akulturasi. Sementara itu, dalam konteks di Indonesia, mengkaji masalah asimilasi di kalangan berbagai kebudayaan adalah suatu hal yang penting untuk menempatkan studi masalah integrasi sosial secara proposional.

\section{PEMBAHASAN}

\section{Akulturasi, Agama, dan Budaya}

Kajian tentang akulturasi yang dilakukan oleh semua ahli antropologi di masa lalu biasanya dilakukan berdasarkan suatu kerangka yang hampir sama, baik di negara-negara persemakmuran, di Amerika Serikat maupun di Amerika Latin. Untuk pertama kalinya, istilah akulturasi dijumpai dalam Webster's Unbridged Dictionary (1928) yang diartikan “...the approximation of one human race of tribe to another in culture or arts by contact." Sampai 1933, pengertian yang terkandung dalam istilah akulturasi sifatnya masih terlampau umum, misalnya yang tercantum dalam Supplement New English Dictionary (1933), yaitu “...the adaption and assimilation of an alien culture." Dalam edisi Webster's Unbridged 
Dictionary pada 1934 arti yang diberikan dalam istilah akulturasi mengalami perubahan yaitu"... the approximation of one social group of people to another in culture or arts by contact; the transfer of culture elements from one social group of people to another."

Kajian tentang pertemuan dua kebudayaan atau lebih bukan hanya berlaku di kalangan tribe dari suatu ras tertentu, melainkan juga lebih menekankan pada suatu kelompok masyarakat. Pada tahun-tahun berikutnya, pembatasan akulturasi mengandung pengertian yang lebih fleksibel, hal itu tampak dalam New Strandard Dictionary (1936), ialah "...the importing of culture by one people to another."

Istilah asimilasi dan akulturasi dalam ilmu sosial, sering dipergunakan tumpang tindih. Sehingga sebagian para ahli berpendapat bahwa istilah asimilasi sering dipakai oleh para ahli sosiologi, sedangkan istilah akulturasi sering digunakan oleh ahli antropologi; dan lebih merupakan istilah spesifik yang lazim dipakai ahli antropologi di Amerika. ${ }^{3}$ Di Jerman, lapangan studi akulturasi lebih dikenal dengan kajian tentang perubahan kebudayaan, sedangkan di Inggris lebih dikenal dengan studi perihal pertemuan dua kebudayaan atau lebih.

Pada dasarnya, pengertian yang terkandung dalam istilah asimilasi dan akulturasi, selain mengandung pengertian yang sama, juga menunjukkan ada dimensi yang berbeda. Sebagai contoh, pembatasan asimilasi yang dibuat oleh Ernest W. Burgess dalam Ensiklopedia of the Social Sciences (1957) antara lain mengatakan"... a process of interpretation and fusion in which persons and groups aquire the memories, sentiments, and attitude of other persons or groups, and by sharing their experience and history, are incorporated with them in a common cultural life." Lebih lanjut Ernest W. Burgess mengatakan bahwa dalam kontak-kontak sosial tersebut yang diawali dengan terjadinya interaksi yang bersifat pribadi dan mendalam, terutama akan berguna untuk meletakkan dasar-dasar dari suatu hubungan lebih lanjut.

Akulturasi menjadi sebuah lapangan studi antropologi di Amerika Serikat dibicarakan pertama kali pada pertemuan tahunan dari American Anthropological Association tahun 1930. Berdasarkan perumusan yang dibuat oleh Robert Redfield, Ralph Linton dan Melville J. Herskovits dari Sub Komite Akulturasi dalam Kongres Social Science Research Council

\footnotetext{
${ }^{3}$ Gordon M.M, 1964, Assimilation in American Life, New York: Oxford University Press, hal. 61
} 
1930, yang dimuat sebagai "Memorandum for the Study of Acculturation", American Anthropologist, Vol. 38 No. 1 (Januari-Maret 1936), h. 136, mengatakan bahwa akulturasi adalah:”... comprehends those phenomena which result when groups of individuals having different culture comes into continous first hand contact, with subsequent changes in the original cultural patterns of either or both groups. ${ }^{4}$

Jika diamati kedua pembatasan tersebut berisikan pengertian mengenai terjadinya pertemuan orang-orang atau perilaku budaya. Sebagai akibatnya kebudayaan mereka saling berubah bentuk. Hal yang tampak membedakannya adalah tidak ditemukannya ciri-ciri struktural dalam pembatasan akulturasi. Dalam pembatasan asimilasi, hubungan yang bersifat sosio-struktural tercermin dari kata-kata "... sharing their experience" dan "... incorporated with in a common cultural life."

Herskovits ${ }^{5}$ berpendapat bahwa makna yang terkandung dalam akulturasi berbeda dengan perubahan kebudayaan (culture change). Akulturasi hanyalah merupakan salah satu tahapan dari asimilasi. Selain

${ }^{4}$ Pembatasan tersebut mendapatkan kritik, sekalipun demikian banyak pula yang tetap berpegang pada definisi dengan disertai beberapa catatan untuk memahaminya, terutama harus selalu dikaitkan dengan keseluruhan dari isi memorandum. Paling tidak ada lima hal yang masih sulit untuk ditafsirkan yaitu a) apa sebenarnya pengertian continous first hand contact, b) apa pengertian dari groups of individuals, c) bagaimanakah hubungan antara akulturasi dengan konsep perubahan kebudayaan dan diffusi, d) bagaimanakah hubungan akulturasi dan asimilasi, e) apakah akulturasi sebagai sebuah proses ataukah menunjukkan pada suatu keadaan (process or condition).

${ }^{5}$ Herskovits mengemukakan dalam Outline Acculturation: the Study of Culture Contact, ada beberapa kajian pokok yang mendapatkan perhatiannya yaitu: 1 . Pembatasan akulturasi; 2. Pendekatan antara lain meliputi a) daftar materi akulturasi, b) cara mengklasifikasikan, c) tekhnik analisis hasil studi; 3. Cara menganalisis akulturasi antara lain meliputi a) tipe suatu kontak dalam akulturasi; b) gambaran situasi dalam suatu masyarakat yang sedang mengalami akulturasi c) proses akulturasi; 4. Seleksi dan mekanisme psikologis yang berkaitan dengan unsur-unsur integrasi dalam suatu akulturasi yaitu meliputi: a) peran individu, b) tipe-tipe kepribadian pihak yang menerima maupun yang menolak unsur-unsur budaya baru c) perbedaan dalam menyeleksi dan menerima unsur-unsur budaya baru yang dikaitkan dengan jenis kelamin, perbedaan lapisan sosial, perbedaan pekerjaan dan perbedaan kepercayaan, d) gambaran keramahtamahan seseorang sebagai akibat rekonsiliasi dalam kebudayaan baru dan hal ini dianggap sebagai faktor integratif dari unsur-unsur kebudayaan baru, e) konflik fisik sebagai akibat upaya rekonsiliasi perilaku sosial tradisional, termasuk berbagai perbadaan sanksi-sanksi sosial; 5. Hasil dari akulturasi apakah berupa acceptation ataukah reaction. Lihat Herskovits, M.J., 1958, Acculturation: the Study of Culture Contact, New York: Peter Smith 
itu, ia juga mengatakan bahwa akulturasi juga berbeda dengan difusi (diffusion) dan semua bentuk akulturasi mengandung pengertian tersebut, terutama dalam kontak fisik dari para pendukung suatu kebudayaan. Lebih lanjut Herskovits menyatakan bahwa difusi merupakan achieved cultural transmission sedangkan akulturasi lebih pada cultural transmission in process.

Semakin banyaknya studi dan penelitian kontak antar kebudayaan di berbagai universitas di negara Eropa dan Amerika Serikat, maka diselenggarakan kongres yang diadakan sekali empat tahun sekali untuk menginventarisasi dan mendiskusikan setiap hasil-hasil penelitian. Kongres itu antara lain pernah diselenggarakan di kota Auckland (New Zealand, 1949); di Manila (Filipina, 1957); Bandung (Indonesia, 1957); dan Honolulu (Hawai, 1961). Pada kongres 1949 itu (the Seventh Pacivic Science Conggress) dilaporkan sebuah karangan dari seorang antropolog bernama Felix Keesing berjudul Culture Change; an Analysis and Bibliography of Antropological Sources to 1952.

Lebih lanjut Arnold M. Rose (1956) juga menjelaskan perbedaan antara asimilasi dan akulturasi. Ia menyatakan bahwa asimilasi adalah "... the adobtion of the culture of another social group a complete extent that the person or group no longer has any characteristict identifying him with his former culture and no longer has any particular loyalities to his former culture. Or, the process leading to this adoption. Atas dasar pembatasan tersebut maka leading to this adoption atau suatu adopsi kebudayaan asing yang demikian luas dan lengkap lebih tepat disebut asimilasi, sedangkan akulturasi dikatakan hanya"... the adobtion by person or group of the culture of another social group adalah akulturasi. Loyalitas mereka terhadap kebudayaan asal semakin kecil dan akhirnya kelompok tersebut mengidentifikasikan dirinya ke dalam suatu kebudayaan baru.

Sebagai akibat perkembangan yang terjadi pada masyarakat Amerika, konsepsi asimilasi mulai dikaitkan dengan aspek politik. Sehingga Robert E. Park ${ }^{6}$ memberikan istilah sebagai asimilasi sosial yaitu: “...the process or processes by which people of divesre racial origins and different cultural heritage, accupying a common territory, achieve a cultural solidarity suffiencient at least to sustain a national existence." Para imigran di Amerika dianggap telah berasimilasi apabila mereka

\footnotetext{
${ }^{6}$ Gordon M.M, Loc. Cit.,
} 
secepatnya dapat menguasai bahasa Inggris dan berperan serta dalam berbagai aktifitas sosial dan politik tanpa menyebabkan timbulnya prasangka. Oleh karenanya, dalam salah satu tulisannya M.M Gordon menunjuk ada tujuh variabel yang harus dikaji dalam asimilasi, dintaranya yaitu:

1. Asimilasi budaya atau asimilasi perilaku atau lazim disebut dengan akulturasi; terjadinya perubahan pola-pola kebudayaan ke arah penyesuaian terhadap kebudayaan kelompok mayoritas;

2. Asimilasi struktural yaitu dalam skala besar mereka memasuki berbagai jenis perkumpulan, klan, dan kelembagaan kelompok mayoritas, terutama pada level dasar atau paling bawah;

3. Asimilasi perkawinan atau amalgamasi (amalgamation) yaitu terjadinya perkawinan campuran dalam skala besar;

4. Asimilasi identifikasi, yaitu berkembangnya perasaan sebagai satu bangsa seperti halnya yang dimiliki oleh kelompok mayoritas;

5. Attitude receptional assimilation yaitu suatu asimilasi yang tercermin oleh tidak timbulnya suatu sikap berprasangka;

6. Behavior receptional assimilation yaitu suatu asimilasi yang dicerminkan oleh tidak munculnya suatu sikap diskriminasi;

7. Asimilasi yang dikaitkan dengan status kewarganegaraan atau civic assimilation antara lain yang terwujud dalam bentuk tidak adanya konflik nilai dan konflik kekuatan.

Berdasarkan uraian di atas dapatlah dipahami bahwa suatu asimilasi mengharuskan para imigran untuk menyesuaikan dirinya pada kelompok kebudayaan yang didatangi (host society). Ini berarti bahwa kebudayaan golongan mayoritaslah yang dijadikan ukuran untuk menilai keberhasilan orang-perorangan atau suatu kelompok dalam menyesuaikan dirinya. Konsep ini sesuai dengan pandangan Arnold M Rose di atas, yaitu identifikasi dan loyalitas mereka terhadap kebudayaan asal semakin kecil dan akhirnya mereka loyal dan mengidentifikasikan dirinya ke dalam kebudayaan baru.

Sementara itu, Frederich E. Lumley dalam Dictionary of Sociology menyatakan bahwa asimilasi adalah "the Proces by which different cultures, or individuals or groups representing different cultures, are merged into a homogenous units." Ini berarti bahwa asimilasi merupakan two way traffic. Oleh karenanya, dalam suatu asimilasi akan dihasilkan suatu kebudayaan baru (melting-pot). 
Menurut istilah akulturasi atau kulturisasi mempunyai berbagai arti menurut para sarjana antropologi. Namun, mereka sepakat bahwa itu merupakan proses sosial yang timbul bila suatu kelompok manusia dengan satu kebudayaan dihadapkan dengan unsur-unsur kebudayaan asing. Sehingga dapat diterima dan diolah dalam kebudayaan sendiri tanpa menyebabkan hilangnya kebudayaan asli. ${ }^{7}$ Akulturasi akan mencakup berbagai aspek kehidupan termasuk di dalamnya adalah bahasa, ilmu pengetahuan dan teknologi serta kesenian. ${ }^{8}$

Ada dua unsur penting terhadap perubahan nilai yang terjadi dalam proses transformasi budaya yaitu terjadinya proses inkulturasi dan akulturasi. Kedua proses tersebut mempunyai hubungan timbal balik dan berganti-ganti, sehingga dapat menimbulkan penghalang atau bisa menjadi pendorong satu sama lain dan mengalami proses kelanjutan atau pembekuan? .

Inkulturasi merupakan penempaan-penempaan setiap individu sebagai subjek kebudayaan, cita-cita kebudayaan yang diharapkan, kontrol melawan penyelewengan dan ketegangan terhadap daya cipta seseorang. Inkulturisasi dianggap berhasil jika terjadi penggabungan antara tradisi dan eksepsi pribadi. Sehingga dengan demikian nilai-nilai dapat berasimilasi secara dinamis.

Di samping, inkulturasi, pada transformasi budaya terjadi pula apa yang disebut sebagai akulturasi. Proses ini merupakan wahana atau area dua buah kebudayaan bertemu, di mana masing-masing dapat menerima nilai-nilai bawaannya. Untuk dapat berhasil dengan baik, proses akulturasi perlu memenuhi beberapa persyaratan, diantaranya syarat persenyawaan (affinity), yaitu penerimaan kebudayaan tanpa rasa terkejut. Gillin mengibaratkan persenyawaan ini sebagai penyerap sebagai bagian organik, sedangkan Amman melihatnya sebagai penjiwaan kebudayaan.

Syarat lain terbentuknya proses akulturasi adalah adanya keseragaman (homogenity), seperti nilai baru yang tercerna akibat keserupaan tingkat dan corak budayanya. Kemudian syarat fungsi, seperti nilai baru yang diserap hanya sebagai suatu manfaat yang tidak penting atau hanya sekedar tampilan, sehingga proses akulturasi dapat

\footnotetext{
${ }^{7}$ Abdurrahmat Fathoni, 2006, Antropologi Sosial Budaya Satu Pengantar, Jakarta: Rineka Cipta, hal. 30

${ }^{8}$ Franklin Books Programs, 1973, Ensiklopedi Umum, Yogyakarta: Kanisius, hal. 30

${ }^{9}$ Andreas Soeroso, 2008, Sosiologi I, Jakarta: Yudhistira Quadra, hal. 63
} 
berlangsung dengan cepat. Dengan demikian, suatu nilai yang tepat fungsi dan bermanfaat bagi kebudayaan sehingga akan memiliki daya tahan lama.

Ciri terjadinya proses akulturasi yang utama adalah diterimanya kebudayaan liar yang diolah ke dalam kebudayaan sendiri tanpa menghilangkan kepribadian kebudayaan asal. Sedangkan Soerjono Soekanto, mengelompokkan unsur kebudayaan asing yang mudah diterima diantaranya adalah kebudayaan benda, sesuatu yang besar manfaatnya dan unsur kebudayaan yang mudah disesuaikan. Unsur kebudayaan yang sulit diterima adalah kepercayaan, ideologi, falsafah dan unsur yang membutuhkan proses sosialisasi. ${ }^{10}$

Para antropolog mencatat beberapa hal yang akan terjadi dalam akulturasi yaitu: ${ }^{11}$ 1. Subsitusi, unsur atau kompleks unsur-unsur kebudayaan yang ada sebelumnya diganti oleh yang memenuhi fungsinya dengan perubahan struktural yang tidak berarti; 2 . Singkretisme, unsurunsur lama bercampur dengan yang baru dan membentuk sebuah sistem baru dengan perubahan kebudayaan yang berarti; 3. Adisi (Addition), unsur atau komplek unsur baru ditambahkan pada yang lama dengan perubahan atau tidak adanya perubahan struktural; 4. Dekulturasi, hilangnya bagian substansial dari sebuah kebudayaan; 5. Originasi (origination); 6. Unsur-unsur baru yang memenuhi kebutuhan baru yang timbul karena perubahan situasi; 7. Penolakan, perubahan mungkin terjadi secara cepat. Sehingga sejumlah orang mungkin tidak dapat menerimanya, sehingga mengakibatkan timbulnya penolakan, pemberontakan atau gerakan kebangkitan.

\section{Agama dan Manusia}

Mengamati sebagian besar manusia dewasa ini didapati kenyataan bahwa agama sangat diperlukan keberadaannya. Keberadaan antara manusia dan agama merupakan dua hal yang tidak dapat terpisahkan. Seluruh agama merupakan perpaduan kepercayaan dan sejumlah upacara. Kepercayaan beragama adalah sekumpulan jawaban yang didasarkan atas ilmu ketuhanan atau penafsiran atas kekuatan-kekuatan gaib terhadap

\footnotetext{
${ }^{10}$ Soerjono Soekanto, 2014, Pokok-Pokok Sosiologi Hukum, Jakarta: Rajawali Pers, h. 112-121. Lihat juga Agus Sachari, 2007, Budaya Visual Indonesia, Jakarta: Erlangga, h. 29

${ }^{11}$ Haviland, William A dan R.G Soekadjo. 1985, Antropologi I, Jilid 2, Jakarta: Erlangga
} 
berbagai pertanyaan mendasar yang ditimbulkan oleh akal pikiran manusia. $^{12}$

Manusia dalam kehidupannya tidak pernah lepas dari pengaruh ajaran agama yang dianutnya. Namun, karena manusia juga sebagai makhluk sosial, sehingga pengaruh tradisi lokal, adat budaya tempat manusia tinggal dan menetap dengan kultur dan budaya yang berbeda, akhirnya akan melahirkan sebuah budaya sendiri-sendiri sesuai dengan lingkungan tempatnya berada. Budaya dan tradisinya tersebut ikut mewarnai perjalanan kehidupannya dari masa ke masa yang melembaga dalam adat istiadat. Lalu terjadi persetujuan dalam proses sosial yang disebut asimilasi antar agama di satu pihak dan budaya di pihak lain. Lebih jauh antar agama dan budaya terjadi akulturasi, yakni terjadi bila suatu kelompok manusia dengan satu kebudayaan tertentu bertemu dengan unsur kebudayaan lain yang berbeda, lalu unsur budaya luar tersebut lambat laun diterima dan diolah ke dalam kebudayaan itu sendiri. Bertemunya suatu kebudayaan dengan kebudayaan yang berbeda terkadang juga melahirkan proses adaptasi, karenanya ada pendapat yang mengatakan bahwa konsep tentang kebudayaan ialah sebagai strategi adaptasi terhadap lingkungan.

Ketika nilai agama bertemu dengan budaya, maka bisa terjadi kesesuaian, atau tidak tertutup kemungkinan yang terjadi adalah sebaliknya, saling berbenturan antara satu sama lain, walapun jarang terjadi. Agama yang dipahami bersifat absolut karena berasal dari ajaran wahyu Tuhan, sedangkan budaya, tradisi dan adat istiadat bersifat relatif karena ia merupakan produk manusia melalui proses alami yang tidak mesti selaras dengan ajaran Ilahiah.

Sebagaimana dipahami, bahwa adat merupakan kreasi manusia yang bersifat kebiasaan yang berlaku dalam suatu budaya masyarakat secara turun-temurun dan dipegang teguh dari generasi ke generasi dan merasuki hampir segala aspek kehidupan yang mengakibatkan seluruh perilaku individu sangat dibatasi. Adat dipandang sebagai karya leluhur yang senantiasa dipertahankan keberadaannya oleh keturunannya sebagai pewaris. Ketika adat istiadat berhadapan dengan ajaran agama, maka akan terjadi saling pengaruh mempengaruhi satu sama lain. Sehingga tidak mengherankan jika keduanya bersentuhan, maka saling mencoba mencari

${ }^{12}$ Francisco Jose Moreno, 1985, Agama dan Akal Pikiran, (Naluri Rasa Takut dan Keadaan Jiwa Manusiawi, terj. M. Amin Adullah, Jakarta: PT. Rajawali Press, h. 121 
pengaruh dan kewenangan. Akibat adanya saling pengaruh tersebut tidak mustahil ada adat yang ditambah, dikurangi atau dihilangkan sama sekali dari ajaran yang semestinya. Inilah yang dalam ilmu antropologi disebut dengan akulturasi, yang secara teoritis akulturasi merupakan proses percampuran dua kebudayaan atau lebih saling bertemu dan saling mempengaruhi yang menurut Robert $\mathrm{H}$. Lauer, bukan berarti kebudayaan yang kuat mempengaruhi yang lemah, namun tergantung pada jenis kontak kedua kebudayaan yang terjadi. ${ }^{13}$ Akulturasi juga bisa terjadi sebagai akibat pengaruh kebudayaan yang kuat dan bergengsi terhadap kebudayaan yang lemah dan terbelakang, dan antara kedua kebudayaan tersebut relatif setara. Walaupun tidak selamanya pengaruh kebudayaan yang kuat atas kebudayaan yang lemah akulturasi terjadi, tetapi tergantung pada jenis kontak kedua kebudayaan tersebut, yaitu seberapa besar kemampuan anggota masyarakat pendukung suatu kebudayaan memaksakan pengintegrasian kebudayaan kepada anggota masyarakat pendukung kebudayaan lain. ${ }^{14}$

Adapun menurut Kuntjaraningrat akulturasi itu sendiri timbul bila suatu kelompok masyarakat dengan suatu kebudayaan tertentu dihadapkan dengan unsur-unsur asing yang berbeda, unsur-unsur kebudayaan asing itu lambat laun diterima dan diolah ke dalam kebudayaan sendiri tanpa menyebabkan hilangnya kepribadian kebudayaan itu sendiri. Hampir senada dengan penjelasan di atas, Sidi Gazalba menjelaskan bahwa akulturasi merupakan sebuh bentuk asimilasi dalam kebudayaan, pengaruh pada suatu kebudayaan oleh kebudayaan lain, yang terjadi apabila kedua kebudayaan saling berhubungan erat satu sama lain. Dalam proses akulturasi, perubahan itu pada dasarnya adalah dalam pengetahuan, cita-cita, perilaku, kebiasaan-kebiasaan individu yang mengalami proses tersebut. Perubahan individu ini menjadi perubahan kesatuan sosial yang dibentuk oleh indvidu-individu yang berubah. ${ }^{15}$

\footnotetext{
${ }^{13}$ Robert H. Lauer, 2003, Perspective on Social Change, Terj. Alimandan, Jakarta: Rineka Cipta, hal. 404-405

14 Jaques Scheuer, 1985, Inculturation; Lumen Vitae, International Review of Religious Education, Washington: International Center for Studies in Religious Education, hal. 12

${ }^{15}$ Sidi Gazalba, 1967, Pengantar Kebudayaan Sebagai Ilmu, Cet-II, Jakarta: Pustaka Antara,hal. 119
} 
Terjadinya akulturasi bisa secara paksaan ataupun sukarela. Secara paksaan bisa dilihat contohnya pada negara-negara yang menjadi jajahan kolonialisme bangsa Eropa terhadap bangsa Timur. Bangsa Eropa memaksakan hal-hal baru pada wilayah jajahannya untuk memeluk agama mereka (kristenisasi), menggunakan bahasa dan hukum peradilannya, memaksakan berpakaian dengan cara modern, mencontoh gaya hidup hedonis, padahal jajahannnya adalah bangsa primitif dan terbelakang. Bila ditinjau dari sejarah kebudayaan Indonesia, dapat dikatakan akulturasi kebudayaan Hindu dan kebudayaan Islam bersifat sukarela, tanpa paksaan. Lain halnya dengan kebudayaan Barat yang cenderung memaksakan kebudayaannya agar diterima oleh wilayah jajahannya.

Hampir senada dengan yang dikatakan oleh Sidi Gazalba, bahwa dalam setiap analisis tentang akulturasi, sejumlah faktor harus menjadi perhatian yang bisa disimpulkan sebagai berikut: Pertama, jumlah orang yang terlibat dalam kontak tersebut, meliputi orang-orang yang terlibat dan hubungan antar mereka; Kedua, kesulitan kedua kebudayaan; Ketiga, tempat terjadinya kontak; Keempat, situasi terjadinya kontak, apakah sukarela atau dipaksakan; Kelima, tingkat ketimpangan sosial dan politik antara kedua kelompok bersangkutan; Keenam, proses seleksi dan proses integrasi unsur-unsur kebudayaan tertentu ke dalam kebudayaan yang menerimanya. ${ }^{16}$

Dari uraian di atas bila dipetakan, maka model akulturasi penjajah terhadap daerah jajahannya dapat termasuk ke dalam akulturasi imperialisme (imperialism acculturation). Adapun model akulturasi yang berjalan sukarela dan berjalan saling mempengaruhi antara satu budaya dengan budaya yang lain, maka termasuk ke dalam kategori accomodated acculturation. Akomodasi yang dimaksud adalah penyelesaian sementara dari perbedaan-perbedaan untuk meredam konflik yang dapat ditinjau dari dua segi, yaitu sebagai suatu keadaan dan sebagai proses. ${ }^{17}$ Pengertian akomodasi sebagai suatu keadaan yaitu merujuk pada suatu keseimbangan dalam proses interaksi, baik menyangkut perorangan, maupun antar kelompok dan antar kebudayaan. Sementara itu, akomodasi sebagai proses merupakan usaha untuk meredakan suatu pertentangan guna mencapai suatu keseimbangan. Adapun istilah lain yang sering

\footnotetext{
${ }^{16}$ Ibid.,

17 Josep Rocek dan Waren Ronald (ed), 1957,Sociology; an Introduction, Lowa Little Field: Adam Co. Ames, h. 41-44
} 
digunakan selain akomodasi adalah adaptasi. Adaptasi yaitu suatu proses makhluk hidup menyesuaikan diri dengan lingkungan tempatnya berada. Di samping itu, bisa bertalian dengan asimilasi, yaitu suatu proses dua kelompok atau lebih yang berbeda, perlahan-lahan mempunyai pola sikap baru yang bersumber dari sikap masing-masing kelompok. ${ }^{18}$

Berdasarkan uraian di atas, disimpulkan bahwa akulturasi Islam dengan tradisi lokal yang terjadi di nusantara digolongkan dalam accomodated acculturation yaitu akulturasi yang mampu saling menyesuaikan diri antara satu budaya dengan lain dengan minim konflik. Sebab yang terjadi adalah adaptasi, yaitu suatu proses tempat makhluk hidup menyesuaikan diri dengan keadaan lingkungannnya. Istilah ini juga digunakan untuk menyebut adaptasi kebudayaan.

Dipakainya teori ini, memungkinkan akan diketahui bagaimana Islam mampu berkulturasi dengan baik dengan budaya yang ada sebelum Islam datang sudah ada pengaruh agama Hindu-Budha dan kepercayaan animisme dan dinamisme. Sebab sejarah Indonesia pada akhir abad ke -20 dilihat dari satu segi adalah sejarah akulturasi. Sebagaimana diketahui, saat kepercayaan dan kebudayaan Hindu datang, maka sesungguhnya telah terjadi akulturasi kebudayaan nusantara dengan budaya Hindu. Akibat akulturasi ini terbentuk corak kebudayaan Hindu dan pernakperniknya. Kemudian saat Islam datang, terjadi lagi akulturasi dengan corak Islam yang memepengaruhi corak kebudayaan lokal.

Jika dicermati dengan seksama, bahwa semangat akulturasi juga bisa dipotret dari sudut pandang agama Islam. Menurut Sidi Gazalba ${ }^{19}$, ajaran Islam mempunyai semangat akulturasi, berdasarkan firman Allah SWT dalam Surat al- Hujarat (49) ayat 13:

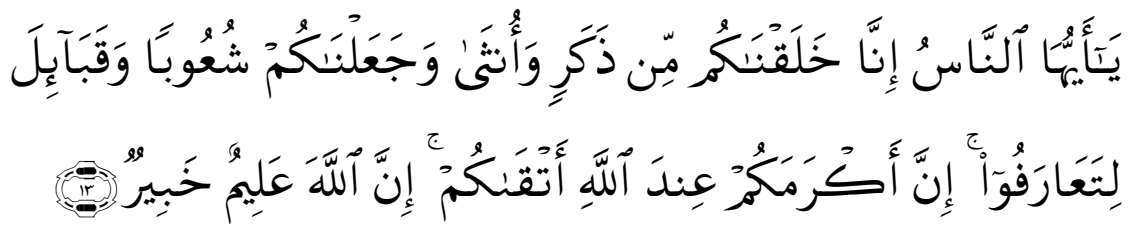

Hai manusia, Sesungguhnya Kami menciptakan kamu dari seorang laki-laki dan seorang perempuan dan menjadikan kamu berbangsa-bangsa dan bersuku-suku supaya kamu saling kenal-

${ }^{18}$ Ratno Lukito, 1998, Pergumulan Antara Hukum Islam dan Adat di Indonesia, Jakarta: INIS, h. 7-11

${ }^{19}$ Sidi Gazalba, op.cit., h. 120 
mengenal. Sesungguhnya orang yang paling mulia diantara kamu di sisi Allah ialah orang yang paling taqwa di antara kamu. Sesungguhnya Allah Maha mengetahui lagi Maha Mengenal.

Ayat di atas mengakui bahwa umat manusia terdiri dari kesatuankesatuan sosial, disuruh saling kenal mengenal karena mereka sudah memiliki kebudayaan tersendiri, maka sebaliknya mengenal dalam kebudayaan untuk terjadinya akulturasi. Nilai kebudayaan dalam Islam bukan terletak pada tingginya derajat kebudayaan, tetapi justru pada nilai ketakwaannya kepada Allah Swt.

Adapun Islam yang dimaksud dalam kajian akulturasi ini adalah agama Islam dalam sebuah sistem nilai, norma yang menjadi sumber dalam spiritual keagamaan, berperilaku, termasuk dalam pemaknaannya dalam kehidupan umat Islam umumnya dan masyarakat nusantara khususnya. Islam dalam penegertian ini yang diambil adalah tidak hanya sebagai sumber nilai yang mengatur masalah spiritual, tetapi juga tentang syari'at dalam arti suatu sistem tatanan sosial yang mengatur cara hidup dan berperilaku. Dengan demikian, Islam sebagai sebuah sistem keyakinan menjadi bagian dan inti dari sistem nilai yang ada dalam suatu kebudayaan dan menjadi penggerak dan pengontrol bagi tindakan untuk sesuai dengan nilai kebudayaan dan ajaran Islam.

Islam yang dimaksud adalah agama yang terus menerus diwahyukan oleh Allah Swt kepada umat Nabi Adam as, sampai kepada nabi akhir zaman Muhammad Saw. Islam inilah yang dijadikan sebagai sumber nilai yang dipegang dan diyakini sebagai sebuah kebenaran yang tertinggi yang menjadi rujukan. Islam dengan seperangkat ajarannya telah membawa nilai-nilai yang revolusioner dan telah mengubah masyarakat manusia dari moral jahiliyah. Islam dengan membawa ideologi baru telah memberikan energi dan keyakinan yang radikal. Sehingga telah mengubah manusia yang sebelumnya tidak menjunjung tinggi nilai-nilai moral ke arah perbaikan dan kebijaksanaan. Islam telah memberikan dorongan bagi sebuah kultur dan kebudayaan zaman baru. Semangat Islam yang menawarkan nilai-nilai luhur ini menjadikan Islam populer dan sangat humanis. Sehingga mampu melewati sekat-sekat budaya dan kepercayaan yang berkembang di masyarakat dengan senantiasa menjunjung tinggi nilai-nilai universal.

Adapun adat adalah wujud dari gagasan kebudayaan yang terdiri atas nilai-nilai budaya, norma, hukum dan aturan-aturan yang antara satu dengan yang lainnya berkaitan menjadi sebuah sistem. Menurut Erni 
Budiwanti ${ }^{20}$ adat atau budaya merupakan suatu kebiasaan yang berlaku turun temurun dari leluhur. Ia mendapatkan keshahihan dari masa lalu, yaitu ketika nenek moyang menegakkan pranata yang diikuti tanpa batas waktu. Sehingga adat secara ideal dapat dipandang sebagai karya leluhur yang harus dipelihara dan dijaga kelangsungannya.

Selain itu, adat yang merupakan sistem nilai yang berasal dari pemikiran mendalam para tokoh masyarakat terdahulu tentang cara mengatur kehidupan masyarakat. Sistem nilai ini diciptakan untuk menjaga keharmonisan dan keselarasan hubungan dengan Tuhan, manusia dan alam. Dalam pemikiran masyarakat nusantara terwujud dalam pemaknaan adat yang diadatkan, yaitu adat yang tumbuh dari mufakat, mengutamakan unsur kebersamaan. Sehingga bila dipetakan, sesungguhnya sistem nilai yang dianut suatu masyarakat, paling tidak ada tiga sumber nilai sebagai pegangan dalam kelangsungan hidupnya. Adapun sumber nilai tersebut yaitu: Pertama, sistem nilai yang bersumberkan pada ajaran agama, Kedua, sumber nilai yang bersumberkan kepada budaya, Ketiga, sumber nilai yang bersumberkan pada adat istiadat.

Sistem nilai yang bersumberkan pada budaya berbeda dengan agama. Sistem nilai yang bersumberkan pada budaya bersumberkan pada faktor kebiasaan yang disampaikan secara lisan turun temurun dari nenek moyang di masa lalu. Karena budaya merupakan perilaku yang dilakukan berdasarkan kebiasaan, maka tidak ada sanksi bagi yang melanggarnya. Kebiasaan tersebut menjadi budaya karena di dalamnya terdapat unsur kebaikan dan bermanfaat bagi masyarakat. Sehingga budaya dapat dilestarikan secara turun temurun kepada anak keturunan. Oleh karena itulah, pola kepercayaan masyarakat yang memberikan penghormatan pada alam, menjadikan timbulnya kepercayaan dan kekuatan supranatural yang berwujud pada sebuah benda biasanya mempunyai kekuatan gaib, adanya makhluk halus di tempat angker. Hal tersebut adalah konsekuensi budaya masa lalu yang mempercayai bahwa semua yang ada di alam jagat raya ini dihuni dan dikontrol oleh makhluk gaib.

Kaitan dengan konteks ini, sangat relevan penelitian untuk mengkaji bagaimana relasi Islam dalam mempengaruhi suatu tradisi dan budaya masyarakat, atau sebaliknya bagaimana aspek-aspek budaya LkiS, h. 48

${ }^{20}$ Erni Budiwanti, 2000, Islam Sasak, Wetu Telu Versus Wektu Lima, Yogyakarta: 
mampu mempengaruhi ajaran-ajaran Islam. Sebab interaksi Islam dengan budaya lokal juga dapat dianalisa dalam konteks sosiohistoris, seperti yang terjadi dalam pola penyebaran Islam ke kawasan Nusantara. Mengenai hal ini, Taufik Abdullah ${ }^{21}$ membedakan tiga pola, pertama, Pasai; kedua, Malaka-Pattani, Gowa-Tallo dan Ternate; ketiga, pola Jawa. Atas dasar pijakan tersebut, ia menyimpulkan secara teoritis pola penyebaran dan pembentukan formasi Islam terjadi pada dua pola, yaitu pola integratif dan pola dialog. Pada dasarnya kedua pola tersebut menunjukan bahwa Islam mengalami proses pembumian dan berhadapan dengan tradisi lokal yang sudah mapan. Sehingga yang sering terjadi terkadang penyesuaian saling pengaruh dan sedikit konflik.

\section{Islam dan Budaya Lokal}

Kedatangan dan penyebaran Islam ke Nusantara memperlihatkan teori dua pola yang berbeda. Pertama, pola buttom-up yaitu Islam terlebih dahulu diterima oleh masyarakat lapis bawah (masyarakat awam), kemudian berkembang dan diterima oleh masyarakat lapisan atas atau elit penguasa. Adapun pola yang kedua, adalah pola top down, yaitu Islam diterima terlebih dahulu oleh elit penguasa, lalu disosialisasikan dan selanjutnya berkembang pada masyarakat bawah. Secara umum dua pola tersebut juga terjadi bersamaan di nusantara, masyarakat lapisan bawah yang berada pada tepian sungai nusantara yang dijadikan sebagai sarana transportasi pada masa lalu lebih dahulu menerima Islam dari penyebarnya, baik melalu proses pergaulan, perdagangan maupun perkawinan dengan saudagar yang singgah dan melakukan interaksi dengan penduduk lokal. Sedangkan pola kedua juga dapat terjadi karena melalui penguasa, rakyat menganut agama dan kepercayaan karena adanya ketaatan dan pengaruh raja atau sultan yang memerintah.

Pertemuan Islam dengan seluruh lapisan masyarakat nusantara yang sudah lebih dahulu memiliki tradisi yang sudah mengakar disebabkan karena watak Islam yang sangat akomodatif dengan adat istiadat dan kebudayaan suatu masyarakat. Islam di luar Arab tidaklah mesti sama dengan Islam yang ada di Arab. Perbedaan ini dilatarbelakangi oleh iklim dan lingkungan turut mempengaruhi budaya, bahasa, perilaku, dan cara berbusana Islam yang antar satu negeri dengan negeri yang lain tentu terdapat perbedaan. Kedatangan Islam ke Nusantara membawa pengaruh

${ }^{21}$ Taufik Abdullah, 1987, Islam dan Masyarakat, Pantulan Sejarah Indonesia, Jakarta: LP3ES, h. 1-9 
yang sangat signifikan terhadap kehidupan keberagamaan masyarakat saat itu. Sebagaimana diketahui, sebelum kedatangan Islam sudah ada kepercayaan yang begitu kuat di nusantara yaitu kepercayaan animisme dan dinamisme, Hindu-Budha.

Dari sekian banyak teori memang banyak yang meyakini bahwa Islam tersebar ke Nusantara dan mampu mempengaruhi penduduknya untuk memeluk Islam adalah atas peranan pedagang muslim. Pendapat ini didukung oleh ilmuan Belanda seperti Wertheim. Namun, ada juga yang menyangkalnya dengan alasan tidak mungkin pedagang muslim tersebut mampu mengislamkan wilayah Nusantara secara besar-besaran dan sangat luas tersebut. Penyangkalan tersebut diwakili oleh Schrieke sebagaimana yang dikutib oleh Azyumardi Azra. ${ }^{22}$

Peranan sufi dalam mempengaruhi berkembangnya Islam di nusantara tidak sedikit. Faktor keberhasilan para sufi dalam mempengaruhi penduduk dari pengaruh Hindu-Budha adalah terletak pada kemampuan kaum sufi dalam mengadopsi keyakinan lokal, tradisi lokal menajadi bagian penting di dalam ritual-ritual Islam yang saat itu masih dipengaruhi oleh corak paganisme dan tradisi Hindu-Budha. Secara atraktif, ajaran Islam dikemas coraknya yang berdekatan dengan tradisi lokal. Sehingga penyebaran Islam berwajah damai, menekankan pada aspek kebatinan atau esoteris. Adanya pemakaian simbol-simbol keagamaan, adanya struktur masyarakat yang berkasta atau bertingkat, serta cara berpakaian semakin menguatkan alasan tersebut.

Hal ini dapat dipahami karena setiap agama tak terkecuali Islam, tidak lepas dari realitas di mana ia berada. Islam bukanlah agama yang lahir dalam ruang yang hampa budaya. Antara Islam dan realitas, meniscayakan adanya dialog yang terus berlangsung secara dinamis. ${ }^{23}$ Ketika Islam menyebar ke Nusantara, Islam tidak bisa lepas dari budaya

${ }^{22}$ Azyumardi Azra, 1994, Jaringan Ulama Timur Tengah dan Kepulauan Nusantara Abad XVII dan XVIII, Bandung: Mizan, h. 24-28

23 Jika ditelusuri lebih jauh, Islam pun merupakan produk lokal yang diuniversalkan dan ditrandensi. Dalam konteks Arab yang dimaksud dengan Islam sebagai produk lokal adalah Islam yang lahir di Arab, tapatnya di Hijaz untuk menjawab persoalan-persoalan yang ada dan berkembang saat itu. Islam Arab itu berkembang ketika bertemu dengan kebudayaan lain, termasuk Indonesia. Oleh sebab itu, Islam senantiasa mengalami dinamisasi kebudayaan dan peradaban. Lihat Pergumulan Hukum Islam dan Budaya Sasak; Mengarifi Fiqh Islam Wetu Telu dalam Jurnal ISTIQRO', Jurnal Penelitian Islam Indonesia, Vol. 06 No. 1, 2007, h. 174 
lokal yang sudah ada dalam masyarakat. Antara keduanya saling meniscayakan adanya dialog yang dinamis, sehingga akhirnya Islam dapat diterima sebagai agama baru tanpa harus menggusur budaya lokal yang sudah ada. Dalam hal ini budaya lokal yang berwujud dalam tradisi dan adat masyarakat setempat tetap dapat dilakukan tanpa melukai ajaran Islam, sebaliknya Islam tetap dapat diajarkan tanpa mengganggu harmonis tradisi masyarakat.

Dialog kreatif antara budaya lokal tidaklah berarti mengorbankan Islam dan menempatkan Islam kultural sebagai hasil dari dialog tersebut sebagai jenis Islam yang rendahan dengan Islam yang murni-yang ada dan berkembang di Jazirah $\mathrm{Arab}^{24}$, tapi Islam kultural dapat dilihat sebagai bentuk varian Islam yang sudah berdialektika dengan realitas di mana Islam berada dan berkembang. Sebagai contoh agama Hindu yang ada di Bali. Hindu di Bali bukanlah agama yang ada di tempat kelahirannya di India, tetapi merupakan hasil dari dialog kultural dan Hindu yang berkembang di Bali. Sehingga internalisasi agama terhadap pemeluknya lebih mudah dipahami dan ajaran-ajarannya dapat diaplikasikan sebagai ideal yang ada dalam agama tersebut.

Menjadi Islam tidak harus menjadi Arab. Islam memang lahir di Arab, tetapi tidak hanya untuk masyarakat Arab. Arabisasi merupakan upaya politik berkedok purifikasi Islam yang berusaha menjadikan Islam menjadi satu dan seragam. ${ }^{25}$ Dalam pemahaman mereka, Islam kaffah

${ }^{24}$ Geertz misalnya memandang Islam bahwa sebenarnya Islam tidak memiliki pengaruh signifikan dalam budaya Jawa. Islam yang disebarkan di Jawa, dinilainya Islam yang sudah ditumpulkan dan dibelokkan ke dalam mistik India. Islam yang demikian terputus dari pusat ortodoksinya di Mekkah dan Kairo. Dengan demikian Islam di Jawa merupakan Islam Sinkretis yang sudah tercampur oleh budaya lokal yang bercorak Animisme-Budhisme-Hinduisme. Cliford Geertz, 1983, Abangan Santri Priyayi, Jakarta: Dunia Pustaka Jaya, h. 170

${ }^{25}$ Ciri utama gerakan Islam ini adalah menjadikan Islam sebagai ideologi politik. Islam dijadikan dalih dan senjata politik untuk mendiskreditkan dan menyerang siapapun yang dalam pandangan politik dan pemahaman keagamaannya berbeda dari mereka. Jargon memperjuangkan Islam sebenarnya adalah memperjuangkan agenda politik tertentu dengan menjadikan Islam sebagai kemasan senjatanya. Selain itu, dengan dalih memperjuangkan Islam dan membelanya, mereka berusaha keras menolak budaya dan tradisi yang selama ini telah menjadi bagian integral kehidupan bangsa Indonesia, dengan menggantikannya dengan tradisi Timur Tengah. Dalam pandangan Gus Dur, ini terjadi karena mereka tidak mampu membedakan dari kultur tempat Islam di wahyukan. Abdurrahman Wahid, 2009, Musuh dalam Selimut, sebuah pengantar pada buku Ilusi Negara Islam; Ekspansi Gerakan Islam Trans Nasional di Indonesia, Jakarta: The 
adalah Islam yang ada dan berkembang di Arab, sehingga seluruh komunitas Islam harus mengikuti pola keberagamaan yang mereka anut dan mereka praktikkan. Tradisi dan adat istiadat setempat bagi mereka merupakan bid'ah yang dapat mencemarkan ajaran Islam. Namun menurut Abdurrahman Wahid $^{26}$, Arabisasi atau proses mengidentifikasi diri dengan budaya budaya Timur Tengah adalah akan tercabutnya kita dari akar budaya kita sendiri. Lebih dari itu, Arabisasi belum tentu cocok dengan kebutuhan kita. Menurutnya antara Islam dan budaya memiliki indepedensi masing-masing, tetapi keduanya memiliki wilayah yang tumpang tindih. Tumpang tindih agama dan budaya akan terjadi terus menerus sebagai suatu proses yang akan memperkaya kehidupan dan membuatnya tidak gersang. Dari sinilah sebenarnya gagasan tentang pribumisasi Islam sangat urgen. Karena dalam pribumisasi Islam tergambar begaimana Islam sebagai ajaran normatif yang berasal dari Tuhan, diakomodasikan ke dalam kebudayaan yang berasal dari manusia tanpa kehilangan identitasnya masing-masing.

Pribumisasi bukan upaya menghindarkan timbulnya perlawanan dari kekuatan-kekuatan setempat, akan tetapi justru agar budaya itu tidak hilang. Oleh karena itu inti pribumisasi Islam adalah kebutuhan bukan untuk menghindarkan polarisasi antara agama dan budaya. Sebab polarisasi demikian tidak terhindarkan. Dengan demikian, pribumisasi Islam akan menjadikan agama Islam dan budaya tidak saling mengalahkan, melainkan berwujud dalam pola nalar keagamaan yang tidak lagi mengambil bentuk yang autentik dari agama, serta berusaha mempertemukan jembatan yang selama ini memisahkan antara agama dan budaya. Dalam praktiknya, konsep pribumisasi Islam ini semua bentuknya dimaksudkan untuk memberikan peluang bagi keanekaragaman interpretasi dalam praktik kehidupan beragama di setiap wilayah yang berbeda.

Bila ditelusuri lebih jauh, pribumisasi Islam di nusantara merupakan keniscayaan sejarah. Sejak awal perkembangannya, Islam di nusantara khususnya di Jawa adalam Islam pribumi yang disebarkan oleh Walisongo dan pengikutnya dengan melakukan transformasi kultural

Wahid Institute bekerjasama dengan Gerakan Bhineka Tunggal Ika dan Ma'arif Institute, h. $19-20$

26 Abdurrahman Wahid, 2001, Pergulatan Negara, Agama, dan Kebudayaan, Jakarta: Desantara 
dalam masyarakat. Islam dan tradisi tidak ditempatkan dalam posisi yang berhadap-hadapan. Akan tetapi, didudukkan dalam kerangka dialog kreatif, di mana diharapkan terjadi transformasi di dalamnya. Proses transformasi kultural tersebut pada gilirannya menghasilkan perpaduan dua entitas yaitu Islam dan budaya lokal. Perpaduan inilah yang melahirkan tradisi-tradisi Islami yang hingga saat ini masih dipraktikkan dalam berbagai komunitas Islam kultural yang ada di Indonesia.

Sehingga dapat dipahami antara agama (Islam) dan budaya (lokal) masing-masing mempunyai simbol-simbol dan nilai tersendiri. Agama Islam adalah simbol yang melambangkan ketaatan kepada Allah Swt. Kebudayaan lokal juga mengandung nilai dan simbol supaya manusia bisa hidup di dalamnya dengan ciri khas kelokalannya. Agama memerlukan sistem simbol, dengan kata lain agama memerlukan kebudayaan agama. Akan tetapi, keduanya perlu dibedakan. Agama adalah sesuatu yang final, universal, abadi (parenial) dan tidak mengenal perubahan-perubahan (absolut), sedangkan kebudaya bersifat particular, relatif dan temporer. Agama tanpa kebudayaan memang dapat berkembang secara pribadi, tetapi tanpa kebudayaan agama sebagai kolektifitas tidak akan mendapatkan tempat.

Lebih lanjut, dialektika antara Islam dan kebudayaan lokal merupakan sebuah keniscayaan. Islam memberikan warna dan spirit pada budaya lokal di Jawa, sedangkan kebudayaan lokal memberikan kekayaan terhadap agama Islam. Hal inilah yang terjadi dalam dinamika keIslaman yang terjadi di Indonesia khususnya di Jawa dengan tradisi dan kekayaan budayanya.

Hal itu dapat dilihat dari kosakata Jawa maupun Melayu, banyak mengadopsi konsep-konsep Islam. Walaupun dengan mengabaikan istilah-istilah kata benda yang banyak sekali dipinjam dari bahasa Arab, bahasa Jawa dan Melayu juga menyerap kata-kata atau istilah-istilah yang berkaitan dengan ilmu pengetahuan. Istilah-istilah seperti wahyu, ilham, wali misalnya adalah istilah-istilah pinjaman untuk mencakup konsepkonsep baru yang sebelumnya tidak pernah dikenal dalam khasanah budaya populer. $^{27}$

Ketika menggunakan istilah-istilah yang diadopsi dari Islam, tentunya perlu membedakan mana yang Arabisasi, mana yang Islamisasi. Penggunaan dan sosialisasi term-term Islam sebagai menifestasi simbolik

\footnotetext{
${ }^{27}$ Kuntowijoto, 1991, Paradigma Islam, Jakarta: Mizan, h. 235
} 
dari Islam tetap penting dan tetap signifikan serta bukan seperti yang dikatakan Gus Dur, menyibukkan dengan masalah-masalah semu atau hanya bersifat pinggiran. ${ }^{28}$ Begitu juga dalam penggunaan term shalat sebagai ganti dari sembahyang (berasl dari kata nyembah sang Hyang) adalah proses Islamisasi bukan Arabisasi. Makna substansial dari shalat mencakup dimensi individual-komunal dan dimensi pribumisasi nilainilai substansial ini ke alam nyata. Adalah naif, ketika mengganti salam dalam Islam (Assalamu'alaikum warahmatullahi wabarakatuh) dengan Selamat Pagi, Siang, Sore dan Malam. Sebab esensi doa dan penghormatan yang terkandung di dalam salam tidak terdapat dalam ucapan Selamat Pagi yang cendrung basa-basi, di samping selain salam itu sendiri memang dianjurkan oleh Allah dan Rasul-Nya.

\section{Interaksi Nilai-nilai Islam dan Budaya}

Perjalanan sejarah manusia, baik yang menyangkut soal sistem keyakinan, kehidupan sosial budaya, ekonomi, politik mapun yang lainnya tidak bisa lepas dari kondisi tatanan geografis dan sosial budaya yang mengitarinya ikut membentuk. Proses ajaran Islam berakulturasi dengan tradisi lokal Nusantara bisa dikatakan berjalan dengan baik. Dalam proses perkembangan selanjutnya, keduanya berjalan beriringan. Hal ini disebabkan karena ajaran Islam memang diperuntukkan kepada semua umat dan golongan, sehingga terbuka untuk semuanya. Kemudian, bagaimana pengikut Islam dapat mempelajari dan memahami ajaran Islam dengan baik dan benar. Di sinilah pentingnya agen akulturasi memainkan peranan pentingnya, karena Islam berasal dari Jazirah Arab sampai ke Nusantara ini tidak lepas dari peran tokoh akulturasi tersebut.

Minimnya konflik ${ }^{29}$ atas penyebaran Islam di Nusantara didukung oleh beberapa foktor diantaranya: pertama, karena watak Islam itu sendiri

\footnotetext{
${ }^{28}$ Abdurrahman Wahid, 1989, Pribumisasi Islam dalam Islam Indonesia, Jakarta: P3M, h. 92

${ }^{29}$ Konflik, kekerasan dan reaksi ekstrim akan muncul apabila agama kehilangan kemampuan untuk merespon secara kreatif terhadap perubahan sosial yang sangat cepat. Dalam tataran ini, para penganut agama harus merenungkan arti perubahan sosial yang mereka alami dan merenungkan perilakunya terhadap situasi baru yang berkembang. Jika agama gagal membimbing umatnya, maka agama akan memasung para pengikutnya pada lembah kebingungan. Sebaliknya jika penganut agama berwawasan jauh dalam merespons perubahan, maka agama akan memainkan peranan penting dalam memenuhi arti kehidupan. Lihat Nur Achmad, 2001, Pluralitas Agama; Kerukunan dalam Keragaman, Jakarta: Kompas, h. 20-21
} 
yang menebarkan kedamaian dan cinta kasih kepada sesama tanpa melihat latar belakang, ras, suku agama, bahasa, dan kebudayaan. Islam juga menghindari terjadinya kekerasan dan paksaan dalam dakwahnya. Sehingga, di manapun Islam disebarkan akan mudah diterima oleh masyarakat. Hal ini dibuktikan dari tidak adanya bukti sejarah yang menceritakan telah terjadi pertentangan dan bentrokan antara Islam dan masyarakat yang didakwahi. Kedua, Islam tidak menghapus seluruh tradisi lokal yang menjadi ciri khas sustu bangsa di saat Islam itu datang, akan tetapi justru tradisi lokal itu dibiarkan tetap berkembang sejauh tradisi tersebut tidak menyangkut kemusyrikan atau yang berhubungan dengan ketauhidan. Atau dengan artian kata, Islam memberi keleluasaan untuk mengekspresikan kebudayaan suatu bangsa tanpa harus dihapus sama sekali. Contoh yang bisa dicermati adalah tradisi Islam yang membolehkan poligami sampai mempunyai empat orang istri, merupakan adaptasi ajaran Islam yang mencoba membatasi tradisi lokal Arab jahiliyah yang memperbolehkan mempunyai istri tanpa batasan jumlahnya. Ketiga, Islam dapat beradaptasi dengan segala bentuk dan warna kebudayaan maupun di bumi ini. Kemampuan Islam dalam bersosialisasi dengan segala macam perbedaan yang ada memunculkan Islam dengan varian tempat Islam itu muncul dan berkembang. Seperti adanya varian Islam Jawa, Islam Sasak, Islam Bugis, Islam Banjar, Islam Lombok dan Islam Buton dengan menonjolkan karakternya masingmasing dan keunikannya sendiri.

Kultur masyarakat Nusantara cukup familiar dengan sesuatu yang baru dan membawa perubahan ke arah kebaikan tanpa harus bersikap frontal dan menentangnya. Datangnya Islam membawa keseragaman umat manusia dalam satu ikatan keyakinan yaitu bendera Islam dan terdapat pula keragaman yaitu perbedaan kultur orang yang mendakwahkannya dengan yang menerima dakwah. Ciri khas Persia sebagai suatu wilayah yang dilewati Islam yang menuju Nusantara banyak memiliki kesamaan dengan unsur Hindu-Budha yang telah menjadi agama yang dianut oleh sebagian besar penduduk Nusantara sebelum Islam datang. Sebagaimana diketahui bahwa agama HinduBudha juga berasal dari kawasan Asia Selatan yang dilewati oleh jalur kedatangan Islam dari sumber aslinya yaitu Arab. Sehingga tidak terdapat kesulitan yang berarti dengan tradisi agama sebelumnya. Namun demikian, proses Parsianisasi tidak dapat dipukul rata sepenuhnya pada proses Islamisasi di kawasan Nusantara dan umumnya Asia Tenggara, 
terutama pada pola dan struktur lembaga-lembaga resmi dan masyarakat serta proses Islamisasi melalui ekspansi militer. Namun proses Islamisasi menemui masyarakat yang telah terbentuk seara mapan dengan suatu pola tertentu yaitu pola Melayu-Hindu yang menjadi karakteristiknya sendiri dan mendominasi sebelumnya.

Proses Islamisasi dengan ide-ide dari kepercayaan tempatan pendahulu Islam. Walaupun Islam mengalami kejayaan, tidak berarti bahwa Islam mampu mengikis habis ide-ide pra Islam sampai ke akarakarnya. Bahkan, yang terjadi kadang adalah sebaliknya, bahwa tradisi lama masih tetap membekas dan tertanam dengan kuat, tetapi sisa-sisa ide dan lembaga pra-Islam itu ada yang lebih kentara pada suatu negeri dari yang ada di negeri lainnya, hal ini juga berlaku di Nusantara. Walau sudah berlangsung kontak cukup lama dengan Islam, nyatanya juga tidak mampu mengubah cara-cara berpikir tersebut dan di banyak daerah kebudayaan atau tradisi asli masih terlalu kuat bertahan dan dilestarikan oleh penduduknya. Berbagai kepercayaan animisme dan dinamisme serta Hindu-Budha yang diganti dengan simbol-simbol Islam. ${ }^{30}$

Uraian di atas menggambarkan sudah terbukti di nusantara, bahwa tradisi Jawa, Sunda, batak, Bugis dan juga termasuk melayu sebagian msih tetap eksis seperti sediakala sebelum datangnya Islam dan berkembang. Namun masih tetap ada yang tidak mampu berubah sepenuhnya walaupun Islam datang meluruskannya. Bila dilihat lebih jauh yang tampak adalah sesungguhnya di luar dibalut dengan kulit Islam, sementara di dalamnya masih tetap kentara semangat kepercayaan pada kekuatan magis sesuatu benda dan tuah serta keramatan suatu tempat, kepercayaan yang seperti ini mereka yakini karena agar mereka selamat dan merasa aman dalam melakukan setiap urusan dan masalah kehidupan lalu memberikan sesajian kepada yang mereka anggap sakral, keramat serta gaib tersebut.

Begitu pula halnya yang terjadi di masyarakat nusantara yang pengaruh peradaban dan keyakinan masa lalu seperti kepercayaan animisme/dinamisme, khususnya pengaruh agama Hindu-Budha yang sangat lama bercokol masih sulit untuk dihapus dengan mudah. Sebab, walau bagaimanapun usaha untuk mengikis habis dalam waktu singkat pengaruh agama dan kebudayaan terdahulu bukanlah perkara ringan.

\footnotetext{
${ }^{30}$ Clifford Geertz, 1973, The Interpretation of Cultures, New York: Basic Book, h. $79-84$
} 
Akan tetapi, diperlukan kemauan segenap komponen umat Islam untuk menacapkan dasar-dasar akidah Islam yang kuat dan tidak hanya sebagai lambang, tapi juga sebagai pandangan hidup/jalan hidup (way of life) tanpa harus mencabut budaya lokal yang sudah ada sebagai identitas dan kekhasan dalam bermasyarakat.

\section{Penerapan Akulturasi di Nusantara}

Adapun contoh penerapan akulturasi di Nusantara antara lain sebagai berikut:

1. Kereta Singo Barong (Cirebon)

Kereta Singo Baron yang dibuat pada tahun 1549, merupakan refleksi dari persahabatan Cirebon dengan bangsa-bangsa lain. Wajah kereta ini merupakan perwujudan tiga binatang yang digabung menjadi satu yaitu gajah dengan belalainya, bermahkotakan naga dan bertubuhkan hewan buraq. Belalai gajah merupakan persahabatan dengan India yang beragama Hindu. Sedangkan kepala naga melambangkan persahabatan dengan Cina yang beragama Budha dan badan buraq lengkap dengan sayapnya melambangkan persahabatan dengan Mesir yang beragama Islam. Kereta ini dibuat oleh seorang arsitek kereta Panembahan Losari dan pemahatnya Ki Notoguna dari Kaliwulu. Pahatan pada kereta itu memang detail dan rumit. Pahatan wadasan dan megamendung mencirikan khas Cirebon, warna-warna ukiran yang merah-hijau mencitrakan khas Cina. Jadi dalam kereta itu, tiga budaya (Budha, Hindu, dan Islam) digambarkan menjadi satu dalam trisula di belalai gajah.

2. Kraton Kesepuhan Cirebon

Bangunan arsitektur dan interior Kraton Kesepuhan menggambarkan berbagai macam pengaruhnya muali dari gaya Eropa, Cina, Arab maupun budaya lokal yang sudah ada sebelumnya, yaitu Hindu dan Jawa. Semua elemen atau unsur budaya di atas melebur pada Kraton Kesepuhan tersebut.

Pengaruh Eropa tampak pada tiang-tiang yang bergaya Yunani. Arsitek gaya Eropa lainnya berupa lengkungan ambang pintu berbentuk setengah lingkaran yang terdapat pada bangunan Lawang Sanga (pintu sembilan). Pengaruh gaya Eropa lainnya adalah pilaster pada dinding-dinding bangunan, yang membuat dindingnya lebih menarik tidak datar. Gaya bangunan Eropa juga terlihat jelas pada bentuk pintu dan jendela pada bangunan bangsal Pringgondani, 
berukuran lebar dan tinggi serta penggunaan jalusi sebagai ventilasi udara.

Bangsal Prabayasa berfungsi sebagai tempat menerima tamu agung. Bangunan tersebut ditopang oleh tiang saka dari kayu. Tiang saka tersebut diberi hiasan motif tumpal yang berasal dari Jawa.

Pengaruh arsitektur Hindu-Jawa yang sangat jelas menonjol adalah bangunan Siti Hinggil yang terletak di bagian paling depan komplek kraton. Seluruh bangunannya terbuat dari konstruksi batu bata seperti laimnya bangunan candi Hindu. Kesan bangunan gaya Hindu terlihat kuat terutama pada pintu masuk menuju komplek tersebut, yaitu berupa gapura berukuran sama atau simetris antara bagian kanan dan sisi kiri seolah-olah dibelah.

Pada dinding kanan dan kiri bangsal Agung diberi hiasan tempelan porselen dari Belanda berukuran kecil 110 x $10 \mathrm{~cm}$ berwarna biru dan berwarna kecoklatan. Pada bagian tengahnya diberi tempelan piring porselen Cina berwarna biru. Lukisan pada piring tersebut melukiskan seni lukis Cina dengan teknik perspektif yang bertingkat.

Secara keseluruhan warna kraton tersebut didominasi warna hijau yang identik dengan simbol Islam. Warna emas yang digunakan pada beberapa ornamen melambangkan kemewahan dan keagungan dan warna merah melambangkan keidupan atau surgawi. Bangunan Keraton Kesepuhan menyiratkan perpaduan antara aspek fungsional simbolis maupun budaya lokal dan luar. Mencerminkan kemajemukkan maupun kekayaan budaya bangsa Indonesia.

3. Barongsai

Kesenian Brongsai yang awalnya berasal dari kebudayaan Tionghoa kini telah berakulturasi dengan kesenian lokal.

\section{PENUTUP}

Berdasarkan pembahasan tentang akulturasi nilai-nilai budaya lokal dan keagamaan, dapat diambil beberapa simpulan sebagai berikut:

Pertama, pertemuan Islam dan tradisi di Nusantara menguatkan konsep adanya keharmonisan Islam dan budaya lokal yang bisa hidup bergandengan dengan nilai masing-masing, yaitu nilai-nilai agama dan nilai-nilai tradisi yang telah berakulturasi dan bersentuhan secara langsung. Keduanya dianggap oleh masyarakat sesuatu yang harus 
dihormati dan dilestarikan. Sehingga hal ini membuktikan adanya jalinan harmoni antara keduanya yang sama-sama melahirkan sebuah ciri Islam yang berintegrasi dan beradaptasi sehingga melahirkan sebuah ciri lokal yang bisa disebut dengan local wisdom.

Kedua, akulturasi merupakan konsep untuk menggambarkan proses panjang bertemunya dua atau lebih tata nilai antara Islam dengan nilainilai lokal di mana individu, kelompok dan masyarakat bertempat tinggal dengan budaya yang telah dimilikinya. Apa yang akan terjadi dalam proses ini seperti subsitusi, sinkretisme, adisi, dekulturasi, originasi, dan bahkan penolakan, harus dipahami sebagai bagian kecintaan mereka kepada nilai-nilai lama (lokal) pada satu sisi dan proses belajar untuk memahami nilai-nilai baru (Islam) pada sisi yang lain. Pada kondisi seperti ini, tidak tepat digunakan klaim menang atau kalah, antara Islam dan budaya lokal.

Ketiga, penerapan akulturasi antara agama dan budaya yang dilakukan oleh Sunan Kalijaga dalam proses penyebaran Islam di tanah Jawa. Sunan Kalijaga, ketika melihat keruntuhan feodalisme kerajaan Majapahit dan digantikan oleh egelitarianisme Islam, ia mendorong percepatan proses transformasi itu, jusru dengan menggunakan unsurunsur lokal guna menopang efektifitas segi teknis dan operasionalnya. Salah satu yang digunakan adalah wayang dan gamelan yang dalam gabungannya dengan unsur-unsur upacara Islam populer adalah menghasilkan tradisi sakatenan di pusat-pusat kekuasaan Islam, seperti Cirebon, Demak, Yogyakarta, dan Surakarta.

\section{DAFTAR PUSTAKA}

Abdullah, Taufik, 1987, Islam dan Masyarakat, Pantulan Sejarah Indonesia, Jakarta: LP3ES.

Azra, Azyumardi, 1994, Jaringan Ulama Timur Tengah dan Kepulauan Nusantara Abad XVII dan XVIII, Bandung: Mizan.

Budiwanti, Erni, 2000, Islam Sasak, Wetu Telu Versus Wektu Lima, Yogyakarta: LkiS.

Clifford Geertz, 1973, The Interpretation of Cultures, New York: Basic Book.

Fathoni, Abdurrahmat, 2006, Antropologi Sosial Budaya Satu Pengantar, Jakarta: Rineka Cipta. 
Franklin Books Programs, 1973, Ensiklopedi Umum, Yogyakarta: Kanisius.

Gazalba, Sidi, 1967, Pengantar Kebudayaan Sebagai Ilmu, Cet-II, Jakarta: Pustaka Antara.

Gordon M.M, 1964, Assimilation in American Life, New York: Oxford University Press.

Hamzah Nunaid, "Asimilasi, Akulturasi, dan Integrasi Nasional", Humaniora, 1999.

Hari Purwanto, "Kajian Kritis Akulturasi Islam dengan Budaya Lokal", Sulesana, Vol. 8, No, 1, 2013.

Haviland, William A dan R.G Soekadjo, 1985, Antropologi I, Jilid 2, Jakarta: Erlangga

Herskovits, M.J., 1958, Acculturation: the Study of Culture Contact, New York: Peter Smith.

Kuntjaraningrat, 1972, Pengantar Antropologi, Jakarta: Aksara Baru.

Kuntowijoto, 1991, Paradigma Islam, Jakarta: Mizan.

Lauer, Robert H., 2003, Perspective on Social Change, Terj. Alimandan, Jakarta: Rineka Cipta.

Lukito, Ratno, 1998, Pergumulan Antara Hukum Islam dan Adat di Indonesia, Jakarta: INIS.

Moreno, Francisco Jose, 1985, Agama dan Akal Pikiran, (Naluri Rasa

Takut dan Keadaan Jiwa Manusiawi, terj. M. Amin Adullah, Jakarta:

PT. Rajawali Press.

Nur Achmad, 2001, Pluralitas Agama; Kerukunan dalam Keragaman, Jakarta: Kompas.

Rocek , Josep dan Waren Ronald (ed), 1957,Sociology; an Introduction, Lowa Little Field: Adam Co. Ames.

Scheuer, Jaques, 1985, Inculturation; Lumen Vitae, International Review of Religious Education, Washington: International Center for Studies in Religious Education.

Sachari, Agus, 2007, Budaya Visual Indonesia, Jakarta: Erlangga.

Soekanto, Soerjono, 2014, Pokok-Pokok Sosiologi Hukum, Jakarta: Rajawali Pers

Soeroso, Andreas, 2008, Sosiologi I, Jakarta: Yudhistira Quadra

Wahid, Abdurrahman, 1989, Pribumisasi Islam dalam Islam Indonesia, Jakarta: P3M, h.

pada buku Ilusi Negara Islam; Ekspansi Gerakan Islam Trans 
Nasional di Indonesia, Jakarta: The Wahid Institute bekerjasama dengan Gerakan Bhineka Tunggal Ika dan Ma'arif Institute, h. 19-20 -----------, 2001, Pergulatan Negara, Agama, dan Kebudayaan, Jakarta: Desantara 